Jusmal lemiah
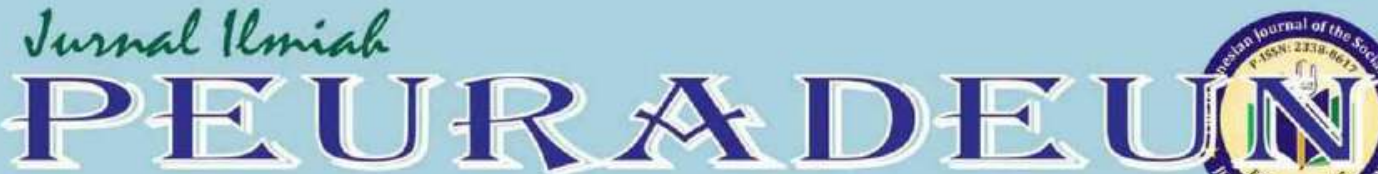

Vol. 8, No. 3, September 2020

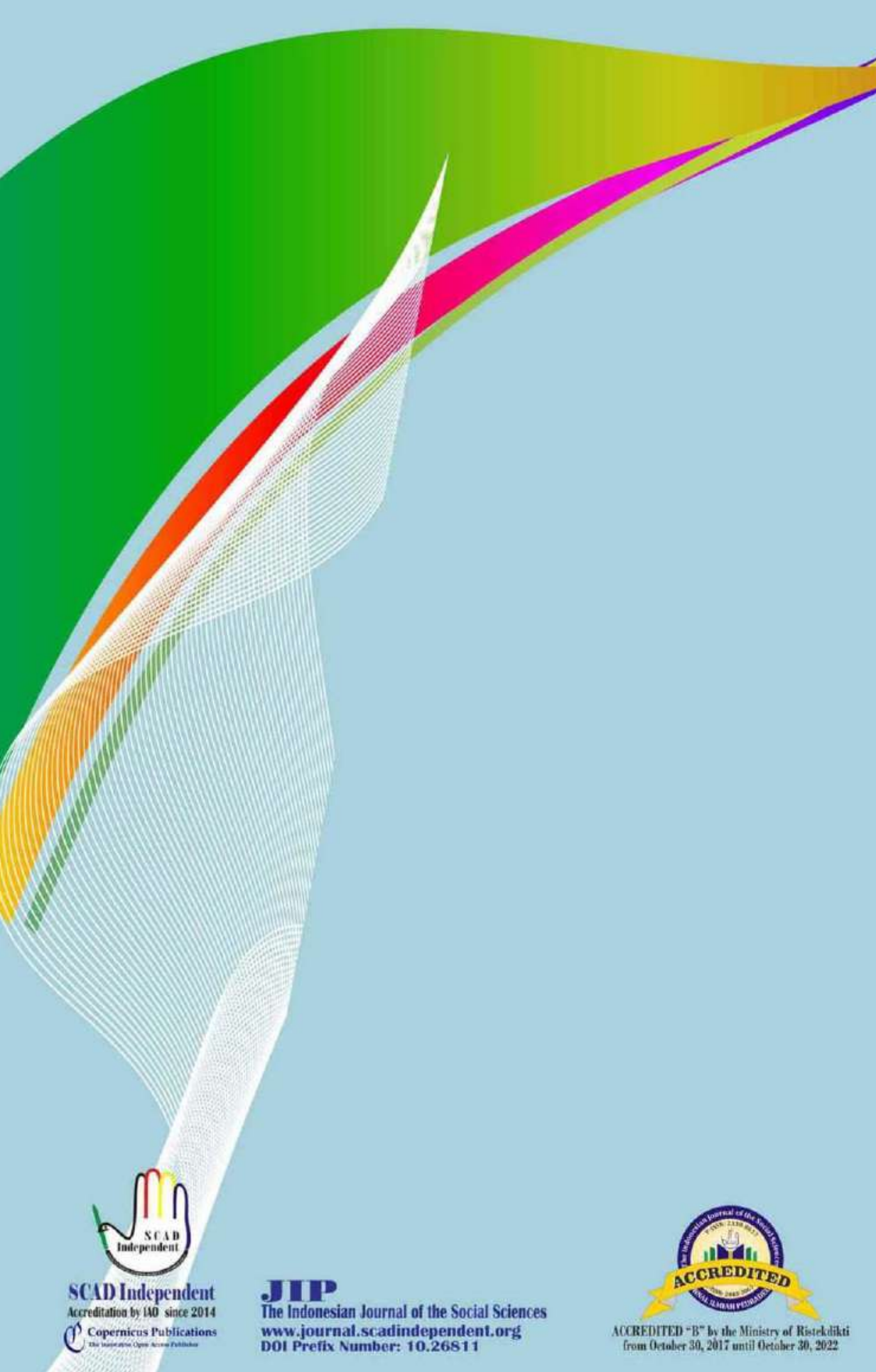

\section{Clarivate Analytics}

Emerging Sources Citation Index Web of Science ${ }^{\mathrm{TM}}$

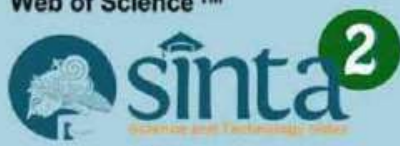

INDEX $\circledast$ COPERNICUS www.journal.scadindependent.org Dot Prefix Number: 10.2681 


\author{
JURNAL ILMIAH PEURADEUN \\ The Indanesian Journal of the Sacial Sciences \\ p-ISSN: 2338-8617/ e-ISSN: 2443-2067
}

www.journal.scadindependent.org

\author{
Vol. 8, No. 3, September 2020
}

Pages: 567-586

\title{
Sundanese Family Strength: A Preliminary Study
}

\author{
Yunita Sari'; Tina Afiatin²; Subandi ${ }^{3}$; H.W.Setiawan ${ }^{4}$ \\ 1,2,3Faculty of Psychology, Universitas Gadjah Mada, Indonesia \\ ${ }^{4}$ Pusat Studi Sunda, Indonesia
}

\begin{abstract}
Article in Jurnal Ilmiah Peuradeun
Available at : https://journal.scadindependent.org/index.php/iipeuradeun/article/view/513

DOI $\quad:$ http://dx.doi.org/10.26811/peuradeun.v8i3.513
\end{abstract}

\begin{abstract}
How to Cite this Article
APA : Sari, Y., Afiatin, T., Subandi, S., \& Setiawan, H. (2020). Sundanese Family Strength: A Preliminary Study. Jurnal Ilmiah Peuradeun, 8(3), 567-586. doi:10.26811/peuradeun.v8i3.513
\end{abstract}

Others Visit : https://journal.scadindependent.org/index.php/jipeuradeun

Jurnal Ilmiah Peuradeun (JIP), the Indonesian Journal of the Social Sciences, is a leading peer-reviewed and openaccess journal, which publishes scholarly work, and specializes in the Social Sciences that emphasize contemporary Asian issues with an interdisciplinary and multidisciplinary approach. JIP is published by SCAD Independent and published 3 times of year (January, May, and September) with p-ISSN: 2338-8617 and e-ISSN: 2443-2067. Jurnal Ilmiah Peuradeun has become a CrossRef Member. Therefore, all articles published will have a unique DOI number. JIP has been accredited by the Ministry of Research Technology and Higher Education Republic of Indonesia (SK Dirjen PRP RistekDikti No. 48a/KPT/2017). This accreditation is valid from October 30, 2017 until October 30, 2022.

JIP published by SCAD Independent. All articles published in this journal are protected by copyright, licensed under a CC-BY-SA or an equivalent license as the optimal license for the publication, distribution, use, and reuse of scholarly works. Any views expressed in this publication are the views of the authors and not of the Editorial Board of JIP or SCAD Independent. JIP or SCAD Independent cannot be held responsible for views, opinions and written statements of authors or researchers published in this journal. The publisher shall not be liable for any loss, actions, claims, proceedings, demand, or costs or damages whatsoever or howsoever caused arising directly or indirectly in connection with or arising out of the use of the research material. Authors alone are responsible for the contents of their articles.

JIP indexed/included in Web of Science, MAS, Index Copernicus International, Sinta, Garuda, Moraref, Scilit, Sherpa/Romeo, Google Scholar, OAJI, PKP, Index, Crossref, BASE, ROAD, GIF, Advanced Science Index, JournalTOCs, ISI, SIS, ESJI, SSRN, ResearchGate, Mendeley and others. 


\title{
SUNDANESE FAMILY STRENGTH: A PRELIMINARY STUDY
}

\author{
Yunita Sari ${ }^{1}$; Tina Afiatin ${ }^{2}$; Subandi ${ }^{3}$; H.W.Setiawan ${ }^{4}$ \\ 1,2,3Faculty of Psychology of Universitas Gadjah Mada, Indonesia \\ ${ }^{4}$ Pusat Studi Sunda, Indonesia \\ ${ }^{1}$ Contributor Email: yunita.sari.psy@mail.ugm.ac.id
}

Received: Jan 24, 2020

Accepted: Jun 7, 2020

Published: Sep 30, 2020

Article Url: https://journal.scadindependent.org/index.php/jipeuradeun/article/view/512

\begin{abstract}
Various studies related to family strength indicators have been carried out in various countries. However, research on family strength in Asia, especially in Indonesia, which has a variety of cultures is still not widely conducted. The purpose of this study was to properly explore key indicators of Sundanese family strength in Bandung City, West Java, Indonesia. This study used the qualitative approach specifically the phenomenology method. The participants were four Sundanese families in Bandung City, who identify its family members are Sundanese and are confirmed by the surrounding community as Sundanese. Data were analyzed with thematic analysis. The result uncovered five themes: 1) accommodating conflict strategy or "silih narima" 2.) positive communication 3.) the emotional intimacy 4.) knowing (philosophy of life) or "neang elmu" 5.) the social support of the family of origin. The implication of these findings is discussed.
\end{abstract}

Keywords: Family Strength; Sundanese; Family; West Java 


\section{A. Introduction}

Research related to family strength with diverse cultural backgrounds is currently still developing in various countries (DeFrain, 2018). However, researchers still have not explored much of the family in Asia, which has diverse cultures (Medora, Larson \& Dave, 2000). Previous research (Kim, Prouty, Smith, Ko, Wetcher, \& Oh, 2014) shown that the importance of research is to use theories that are appropriate and under the context of family culture. Lestari (2012) and Afiatin (2018) also state that cultural context becomes an essential element that should be concerned with understanding various problems in the family.

The Sundanese are the second-largest ethnic groups in Indonesia who mostly lived in the region of West Java Province (Ekadjati, 1984). West Java is inhibited by more 49 million people and is currently the largest population in Indonesia (Kusnandar, 2019). West Javanese people are usually called urang Sunda (Sundanese) (Suryadinata, Arifin, \& Ananta, 2003; Ekadjati, 1984). The Sundanese have a different language, culture, and history to the Javanese in central and eastern Java (Riyani \& Parker, 2018).

The history of Sundanese shows that marriage and divorce due to polygamy and infidelity often occur either among functionaries or among society (Lubis, 2000), however, there are many other functionaries and society maintain the integrity of marriage. Some studies related to stereotyping on Sundanese men and women are conducted in the field of media (Prasetyo, 2013; Utaridah, 2015). Both studies conclude that the media affect the stereotype to Sundanese, especially negative stereotype related to the male-female relationship. Utaridah (2015) in her article states that a stereotype called "tukang kawin" or marrying maniac refers to Sundanese men because they are considered humorous, jolly, and polite so that many women feels comfortable and easy to fall in love to whom. Moreover, the stereotype to Sundanese women described by the myth is a negative woman due to their ideal physical appearance, materialistic, lazy, good at grooming, dependent on husband's income, a teaser, and a destroyer other people's romantic relationship (Prasetyo, 
2013; Siddik, 2015). Increasingly widespread of the stereotype of Sundanese men and women shows that there is a social and cultural aspect related to family problems.

Based on literature studies on literary works, Sundanese fiction and research related to Sundanese society, it is also known that some characteristics of Sundanese women with negative connotations are being reactive, more emotional and more easily influenced by their social environment (Suryani, Diria, Adipurwawidjana, Erlyane \& Hudayat, 2002; Iskandar, 2012). Some of these characteristics appear to be in line with the results of Sururie and Yuniardi's research (2018) related to the causes of divorce from economic factors in the Sumedang and Ciamis (West Java) regions, namely the wife cannot stand being in a poor economic condition, often comparing family assets with neighbors and demanding better life worthy of a good husband. Although Sundanese families are stereotyped vulnerably to divorce, on the other hand, some Sundanese families are lasting and show happy and well-functioning families. Research related to "menak" women (aristocratic woman in the structure of Sundanese community) shown that the good husband-wifechildren interaction in the family was accomplished and therefore, family functioning was achieved (Marlina, 2006).

Understanding the Sundanese today is a great challenge to scholars (Roger, 1999). This is because Sundanese is an open and easily receptive society to outside influences which then absorbs the influence so it becomes its own (Rosidi, 1984). Keeping Sundanese culture alive amid globalization is a challenge for Sundanese, especially in family life to build a strong family.

\section{B. Literature Review}

According to Act No. 10/1992 on population development and constructing well-off family, the definition of family resilience is a dynamic condition of a family with tenacity, strength, material prosperity, psychological, mentality and spirituality to independently live, develop oneself and family to gain harmonic condition in 
improving spiritual and physical well-being. According to Sunarti (2015) family strength is a family's ability in managing resources and family problems, they attempt to achieve good quality and prosperous life with the value that they believe. Family resilence (physical-economical strength, social strength, and psychological strength) is expressed by meeting the roles, functions, and family task, and how a family interact in the life span. Family strength is holistic, so that the psychological research focuses on the capability of a family to overcome non-physical problems, to positively control emotion, and to have positive self-concept (including hope and satisfaction) and a care of the husbands toward his wife (Puspitawati, 2012). Iqbal (2018) defines family psychological strength as the capability of family members to manage their mental health like managing emotion, stress, life motivation, interaction with other members, decision making and conflict, so that it is expected the members develop and run their functions well.

The definitions by Puspitawati and Iqbal are not based on the research related to psychological strength of family in Indonesia. In theoretical frame, psychological strength of family is based on terminology of family strength. Family strength by Moore, Chalk, Vandivere, \& Scarpa (2002) is defined as the set of relationships and processes that support and protect families and family members, especially during times of adversity and change. Meanwhile, Trivette, Dunst, Deal, Hamer, Propst (1990) states that family psychological strength is competence and capability of all family members and family unit employed to face crisis and stress, to meet needs, and to promote, improve and strengthen functions of family system. Therefore, the core of family psychological strength is competence and capability of family members and family unit which are used to respond crisis and stress, to meet needs, to improve and strengthen family system.

Researchers have attempted to identify and measure family strength variable for the last decades. Otto (1962) is a pioneer to identify what makes a family strong, he was later followed by Stinnett and other researchers (Stinnet, 
Chasser, \& DeFrain, 1979). Later on, Olson (2000) also tried measuring a family which functions based on dimensions of cohesion, flexibility and communication. Meanwhile, Defrain (2018), one of Stinnet's colleagues, found the similarity of family strength characteristic in various countries, the presence of rewards and affection, commitment, positive communication, pleasureable togetherness, spiritual well-being, an ability to overcome stress and crisis effectively. Other figures also explored the indicator of family psychological strength among minority and various ethnicities.

Even though there are various theories on family strength, Brotanek, Rocha, and Flores (2008) had different argument that study on family strength could be unseparated from one's cultural context. Those researchers thought the importance of tradition and culture helped parents to nurture their children (Brotanek, Rocha \& Flores, 2008.). Most of the family strength researchers focused on white family than minority family (Lee, 2000; Littlejohn Blake \& Darling, 1993; in Wong, 2012). According to other researcher (Medora, Larson \& Dave, 2000), the research on family strength Asia multicultural countries are still less explored.

Studying about family strength based on cultural or cross-cultural perspective could employ etic and emic approach (Setiono, 2011). Etic approach produces generalization, while the emic approach seeks for family uniqueness based on social-cultural condition. Surely, there is the controversy on both, however DeFrain \& Asay (2007) choose the etic approach (universal). Community perspective on family's psychological strength is useful to ensure that meaning, value, norm of a culture can be a foundation to create an interpretation (Setiono, 2011). Brotanek, Rocha, and Flores (2008) also emphasize on context of family culture to understand family's psychological strength or family strength. Several studies related to indicators of family strength of various countries are shown in table 1.

\begin{tabular}{lcl}
\hline \multicolumn{1}{c}{$\begin{array}{c}\text { Family strength } \\
\text { theories }\end{array}$} & $\begin{array}{c}\text { Country's } \\
\text { Family }\end{array}$ & Indicators of family strength \\
\hline Stinnet (1979) & USA & $\begin{array}{l}\text { Appreciation and affection, commitment to the } \\
\text { family, positive communication, enjoyable time } \\
\text { together, spiritual well-being and shared values, }\end{array}$ \\
$\begin{array}{l}\text { Stinnet, DeFrain } \\
\text { and colleagues }\end{array}$ & & \\
\hline
\end{tabular}




\begin{tabular}{|c|c|c|}
\hline $\begin{array}{l}\text { Family strength } \\
\text { theories }\end{array}$ & $\begin{array}{l}\text { Country's } \\
\text { Family }\end{array}$ & Indicators of family strength \\
\hline$(2002,2007,2018)$ & & the ability to manage stress and crisis \\
\hline Olson (2000) & USA & Cohesion, adaptability and communication \\
\hline $\begin{array}{l}\text { Kryson, Moore dan } \\
\text { Zill (1990) }\end{array}$ & USA & $\begin{array}{l}\text { Commitment to family, time together, } \\
\text { encouragement of individuals, ability to adapt, } \\
\text { clear roles, communication, religious orientation, } \\
\text { social connectedness }\end{array}$ \\
\hline $\begin{array}{l}\text { Wong, Wong dan } \\
\text { Obeng (2012) }\end{array}$ & $\begin{array}{c}\text { Asian } \\
\text { American }\end{array}$ & $\begin{array}{l}\text { Provision of practical help, open communication, } \\
\text { recreational activities, respect for children's } \\
\text { autonomy, comparisons with other Asian } \\
\text { American families, parents sacrificial love }\end{array}$ \\
\hline
\end{tabular}

\section{Method}

This research uses qualitative approach with phenomenology method. Data collecting techniques are interview and observation on four families, field notes and two crosscheck Informant in Bandung City. The participants in this research are obtained by using purposive sampling with criteria type (Creswell, 2014). Criteria of the participants are:

1. A family who identify its family members are Sundanese and are confirmed by the surrounding community as Sundanese (Suryalaga, 2009);

2. Being domiciled in Bandung City;

3. Undergoing the first marriage for minimum 20 years. The 20-year marriage refers to one of the indicators of successful family i.e. long-lasting (DeGenova, 2005);

4. At least has one adolescent child. It is based on the research by Sari, Kurnia \& Sundaya (2016) that the highest divorce in Bandung City took place in a family who had adolescent kid;

5. Every family varies in term of address, total children, divorce or not divorce;

Data analysis used thematic analysis. Thematic analysis is one way to analyze data with the aim to identify patterns or find themes through data that has been collected by researchers (Braun \& Clarke, 2006). First, 
the researcher reread the interview transcript and listens to the recording of the interview. Second, researcher independently coded the data for each family. Third, researcher grouping the data into themes.

\section{Results and Discussion}

\section{Results}

This part shows the description of each family. As part of research ethic, pseudonym is used to protect the family's identity. The summary of the participants' socio demography can be seen in table 2 .

Table 2. Sosio-demography of the participants

\begin{tabular}{|c|c|c|c|c|c|c|c|c|}
\hline No & Family & Status & $\begin{array}{l}\text { Name } \\
\text { (pseudonym) }\end{array}$ & Age & $\begin{array}{l}\text { Number } \\
\text { of } \\
\text { Children }\end{array}$ & education & occupation & $\begin{array}{l}\text { Length of } \\
\text { Marriage }\end{array}$ \\
\hline \multirow[t]{2}{*}{1.} & $\mathrm{~A}$ & Mother & Amel & 46 & 10 & $\begin{array}{l}\text { College } \\
\text { graduate }\end{array}$ & $\begin{array}{l}\text { Tailor and } \\
\text { Traider }\end{array}$ & $\begin{array}{l}23 \text { years } \\
\text { and } \\
\text { divorced }\end{array}$ \\
\hline & & Child & Adinda & 21 & & $\begin{array}{l}\text { Vocational } \\
\text { School } \\
\text { graduate }\end{array}$ & $\begin{array}{l}\text { On job } \\
\text { searching }\end{array}$ & \\
\hline \multirow[t]{2}{*}{2.} & $\mathrm{~T}$ & Mother & Tari & 56 & 2 & $\begin{array}{l}\text { College } \\
\text { graduate }\end{array}$ & Teacher & $\begin{array}{l}24 \text { years. } \\
\text { No status } \\
\text { since 2008- } \\
2016, \\
\text { officially } \\
\text { divorced } \\
\text { (2017) } \\
\text { \&remarried } \\
(2018)\end{array}$ \\
\hline & & Child & Tono & 23 & & $\begin{array}{l}\text { College } \\
\text { graduate }\end{array}$ & $\begin{array}{l}\text { (Fresh } \\
\text { Graduate) } \\
\text { On job } \\
\text { searching }\end{array}$ & \\
\hline \multirow[t]{3}{*}{3.} & $S$ & Father & Sarif & 67 & 1 & $\begin{array}{l}\text { Diploma } \\
\text { graduate }\end{array}$ & Retired & 37 years \\
\hline & & Mother & Sinta & 61 & & $\begin{array}{l}\text { College } \\
\text { student } \\
\text { (unfinished) }\end{array}$ & Housewife & \\
\hline & & Child & Sasa & 21 & & $\begin{array}{l}\text { College } \\
\text { student }\end{array}$ & $\begin{array}{l}\text { University } \\
\text { student }\end{array}$ & \\
\hline \multirow[t]{3}{*}{4.} & $\mathrm{M}$ & Father & Maman & 60 & 4 & $\mathrm{PhD}$ & Lecturer & 30 tahun \\
\hline & & Mother & Mirna & 55 & & $\begin{array}{l}\text { College } \\
\text { graduate }\end{array}$ & Teacher & \\
\hline & & Child & Mayang & 27 & & $\begin{array}{l}\text { Magister } \\
\text { Student }\end{array}$ & $\begin{array}{l}\text { Artist/ } \\
\text { Magister } \\
\text { Student }\end{array}$ & \\
\hline
\end{tabular}


The researcher found 5 themes in this study:

\section{a. Accomodating conflict strategy or silih narima}

In a divorced family, Amel and Tari's family, conflict resolution was occurs along with violence. The violence does not only happen between the wife and the husband but also between the parents and the kids, and among kids. Tari share a story about a fight with her husband:

"...Husband (my husband), admonished "mam, I don't have any affair with that woman. There is no affair. You should not hurt other people". "I don't know, it is said that my husband went with the woman. The birthday is in October, I remember that." "Who said that!....." Getting angry! And then he kicks when being angry" (T.L/200-204).

In intact family, conflict revolution is done strategically, with problem-focused way and by accepting one another. Sarif told that the problem was solved by "talking" and knowing right time to talk.

"By talking. We usually become relented mam. So.... It is not relented actually. Errrr for instance I get angry. While I am continuously angry, she is silent. Nah, when she is angry, turn back back back.... she is mad.(laugh). So, it is like that" (S.M.1/217-219).

\section{b. Positive communication}

Sarif and Maman have open communication with their family, become appreciative during talking and discuss with their children in the right time. Maman told that he was happy to discuss with his children about anything including the jobs. He asks for his children's opinion. "....if I have something, I always eee discuss with my children. As always.... for example jul what about today?... your father has this job... which alternatives are better. There are always some alternatives... pick this one father, and it is better. And then I ask again... and become happy.I am fine to have problems because in our family, because we have a deal.... and if there will be a conflict, our intuitions know it. It must be like this... we show that we must know about conflict. We must know it. There must be an end." (M.T.2/363-374)

Tari explained he was not open with her husband hence emerging disappointment in their relationship. She wished her husband had known her feeling without she expressed that. 
"...It is true my communication is not good. I am unopen, so is he. For example, I actually wanted to be walked to the school, but I did not say it. When I was walked to Sunda street, I actually wanted to be walked to in front. However, he did not do that, there was a disappointment. A disappointment, I also become disappointed because he is angry if something happens...." (T.1/80-85).

\section{c. Family's emotional intimacy}

Sarif's family is emotionally attached to one another. Sinta told how the attachment of her husband and her only child. "yes, very close. Frolicking and making joke with her father. My sister's child is asked to sit with her father, but she doesn't want, he doesn't want to be pictured, he said to delete it from your phone. But my daughter looks like a sister to my husband, making joke with her daddy "(S.S.R.1/164-168)

Adinda told she did not attach to her father. She only talked when it was important. Her father was rarely at home and often spent time with his friends. Adinda also told that when they walked around, and her father spent more time using his mobile phone.

“...we rarely walked around together. We go to city square at very least. But today, gadget becomes so good that the child can play, and my father keep being with his mobile phone wherever we go" (T.Q/261-263).

\section{d. Having knowledge (philosophy of life) or neang elmu}

In every family, some values are believed and taught by parents to their children. In Sarif's family, Sarif and Sinta often remember advice from their parents about family. In addition, they make their parents' behavior in facing problems, interacting with partner and nurturing children as a model. Sarif and Sinta also teach religion and Sundanese culture to Sasa. Sasa said her parents taught her to be equal and balance between religion and social behavior in community.

"it is more about moral, relationship with human and God must be balance. You should not only do zikr and prayer to be a good person, but also you should be good to other people, being polite and having ethic and so on, my parents emphasize that. When talking to other people, we should be open-minded, we should not force our opinion, it will create conflict" (S.R.1/51-60). 
In a divorced family, Tono explained his family had lack of religious teaching. His father and mother rarely did prayer and often had conflicts. Tono studied religion in his social environment, especially from his schoolmates.

".....it is true that religious teaching in my family is so little, so I learn about religion by myself. I look at my friends.. I often learn about it from friends, they often tell me about the prophet. if our friend is a perfume seller, we will get the fragrance too..after that..just like.. even though our friend is a bad guy, we will not be like him.." (T.L/253-257).

\section{e. Support from family of origin}

Sarif and Sinta were introduced by their family of origin. Since then, Sarif and Sinta underwent a long-distance relationship because Sarif worked in Sumatera. Since they were introduced, their original family has been involved and has supported Sarif to marry with Sinta.

"My brother is in Bandung because my father and mother are in the hometown, in Tasik, so far. My parents always said "this age is hurry to get married", like usual. yes..later. Nah, at last I was forced and I said. Alright, please find a woman for me.. and then...."alright.. go back here...there is a neighbor here,let you meet her"." Accidentally the woman's house is near Sekelimus di Cigadung, around here, in Sekelimus" (S.M.1/6-11)

This condition is different from the divorced family. Since Tari and partner (Tata) knew each other, their family did not really agree with their relationship. It happened to Tari's family. Tari's family of origins did not agree with Tari and Tata's getting married. According to Tari's mother and grandmother, her future husband was rude man. However, what her mother and grandmother said was ignored by Tari at that time.

"my family did not agree at first...because he was rude. Because he was easy to be angry. Because he used to hit. Because of it. (T.1/21-23) "moreover, it got caught by my grandmother. By my grandmother. It got caught by my grandmother. "Daughter, don't marry him." Eh, and then my grandmother spoke to my mom.. she kept telling my mother, and my mother became shocked and did not like. However, because I liked him, I did not like what they said, why? Because I thought that most of my 
Yunita Sari et al.

friends were from rich family (having money), but he had no mother. His mother passed away, and his parents got divorced " (T.1/25-31).

\section{Discussion}

The aim of this study was to explore the indicator of psychological strength of Sundanese family. Some indicators were same as the previous researches (DeFrain, 2018; Kryson, Moore \& Zill, 1990; Wong, Wong \& Obeng, 2012). The finding on accommodative conflict strategy or silih narima is the same as the ability of facing stress and crisis (DeFrain, 2018), adaptability (Olson, 2000), ability to adapt (Kryson, Moore, \& Zill, 1990). Positive communication theme is the same as positive communication (DeFrain, 2018) open communication (Wong, Wong \& Obeng, 2012), communication (Olson, 2000; Kryson, Moore \& Zill, 1990). Family's emotional intimacy theme is the same as social connectedness (Kryson, Moore \& Zill, 1990), appreciation and affection (DeFrain, 2018), cohesion (Olson, 2000). Meanwhile, seeking knowledge indicator (philosophy of life) or "neang ilmu" and support from family of origin is different from previous research (see table 1).

\section{a. Having knowledge (philosophy of life) or "neang ilmu"}

Seeking for knowledge and mastering some knowledge are necessary in philosophy of Sundanese (Warnaen et al, 1987). Having knowledge of family and teaching knowledge inside Sundanese family was stated by all participants. In Sundanese culture, there is a proverb "gede luang, legok tapak" (Warnaen et al, 1987). The meaning of the proverb is the Sundanese should have many experiences. Having many experiences is related to how Sundanese obtain knowledge. In Baruang Ka $\mathrm{Nu}$ Ngarora story book (Ardiwinata, 2017), Tuan Raup Abdul Raup advised his married daughter, "Kawajiban awewe lalaki kudu ngulik elmu nu baris mangpaat. Pikeun awewe nya salaki anu baris nungtun-nungtun. Lamun manehna teu bisaeun, wajib kudu ihtiar, di kengkenkeun ka nu sejen". The meaning is the obligation of men and women are seeking for useful knowledge. If the women are unable, the men must direct them. If the 
husbands are unable, they must try hard, it could be by asking others' help. The words above means that there is an obligation for Sundanese family to learn and seek for knowledge or "elmu" (Setiawan, 2011).

Setiawan (2011) also explains that literary work, namely wawacan Panji Wulung, tells about advice from parents to the younger generation to prioritize reasoning in act, consider the pros and cons of the consequences of their actions. In addition, it was emphasized that success can be achieved by learning and practice skills.

Mastering knowledge which is expressed in the Sundanese proverb above is basically addressed to knowledge on philosophy of life. Sundanese must study the meaning of life that they undergo so that the knowledge is not just about the educational title held by the Sundanese. The philosophy of life is also taught through the values of religion. It is in accordance with Sundanese proverb "Jelema teu cekap bageur wungkul da kedah beragama". It means an individual should only be ungood, but also be religious. It is also promoted by Sundanese tradition that said "Sundanese must get religious teaching" (Warnaen, 1986). In psychological studies it is known that religious rituals encourage positive relationships within the family (Jamil, 2019).

The philosophy of life in Sundanese family is taught by parents or social community through advice or good examples. According to Warnaen, Djiwapraja, Wibisana, Adimijardja, Sukmana \& Rostoyati (1986), learning the philosophy of life could from a father, a mother, to people inside family, to knowledgable person or learning from the failure, the example, the book, the independent thinking, and matters found on the way.

\section{b. Support from family of origin}

Support from family of origin becomes a different theme from the previous research (see table 2). Original family is a family in which an individual was born or adopted. The original family is the first family in which an individual is nurtured and grows (Langmead, 2018). Support from original family, either from husband or wife's family, is regarded to the process of building psychological strength in Sundanese family. All 
participants stated that original family supported them when they were in hard moment. For Sundanese family, relatives should help one another if they get difficulty and should forgive one another if they made a mistake despite a bad family (Warnaen, Djiwapraja, Wibisana, Adimijardja, Sukmana, \& Rostoyati 1986).

In Sundanese family, support from original family has been showed before the marriage is held. At first phase marriage "nanyaan" or "neundeun omong" (husband's family proposes wife's family), original family has known the bad and the good of that future partner. Sundanese people believe that the mechanism of proposing woman to be a wife should be done in a very decent way. Therefore, advice from parents or family should be well considered. Sundanese proverb says that advice from parents, teachers, and queen should be put on the top (Warnaen et al, 1987). Therefore, support from family of origin during marriage can determine the psychological strength of Sundanese family.

The themes which are same as the previous research (see table 2), like accommodative conflict strategy or silih narima, positive communication, and emotional intimacy, are also found in this study, but the forms of behavior are typical Sundanese.

\section{c. Accomodating conflict strategy or silih narima}

Defrain (2018) states that accommodating conflict strategy or silih narima nearly resembles the ability of overcoming stress and problems.However, in Sundanese family, Sundanese people tend to solve problems by avoiding conflict. It is in accordance with the Sundanese proverb "laukna beunang, caina herang" which means that the fish get caught but the water is still limpid. It means that the importance of achieving the purpose by wise way without ruining the condition. In facing problems, Sundanese people usually find the best and wisest way. As the Sundanese proverb "bandung kandungan laer aisan" which means being wise in facing various problems. Therefore, the response of Sundanese people in facing the problem can be made by "malapah gedang" (step by step) or "malipir" not strictly to the problem. The "malapah gedang" or "malipir" strategy is used 
by Sundanese family to avoid conflict. Even though those strategies are not fully effective in overcoming the problem, those could be the assets because they can reduce the bigger conflict happening in Sundanese family. Therefore "malapah gedang" or "malipir" can be a way to extend time to think or soothe negative emotions emerging during the conflict to get good way to solve the problem.

However, the Sundanese proverb "caina heurang laukna beunang" is also undirected to the aim precisely, but it refers to the attitude and actions taken by Sundanese family in solving the problem. Sundanese people will see kinds or forms of the problem that they face, so that they can make right decision. It can be seen in the steps which are taken by an individual in making decision, it is written in Baruang $\mathrm{Ka} \mathrm{Nu}$ Ngarora book i.e. "nista, maja, utama" (Ardiwinata, 2017). A piece of story in the book Baruang $\mathrm{Ka} \mathrm{Nu}$ Ngarora shows that there are steps of one's mistake because doing bad things. However, the principles of "nista, maja, utama" can be understood that "utama" is a good action to take and "nista" is a bad action to take. When solving the problem, one should focus on "utama". The better way," utama", should be taken from the conflict or the problems.

\section{d. Positive communication}

The participants also said the importance of positive communication. The importance of communication is also stated in Sundanese proverb "hade $\mathrm{ku}$ omong goreng $\mathrm{ku}$ omong". It means it is more important to speak than to be silent when there is a matter or problem. Close behavior in communication can affect the relationship in Sundanese family. Beside the openness in communication, communication inside family is also related to how to convey information. It is in accordance to the Sundanese proverb "Nyaur kudu di ukur, nyabda kudu dungang." It means that all actions must be taken into consideration before they are conveyed, an individual also must have a selfcontrol in talking (Warnaen, 1986). It shows that in communication Sundanese family expresses what they feel by using good way and need to have selfcontrol on what one says. Sundanese family usually becomes balance, it means they know the right time to speak and understand the good way to speak. It is 
in accordance with an the Sundanese proverb "kudu bisa metakeun ilat-ilat, metakeun duduga peryoga" (Ardiwinata, 2017).

\section{e. Family's emotional intimacy}

Family's emotional intimacy is showed by Sundanese family by meeting, spending time, joking, sharing and doing a happy activity with family so that the family can feel warmth and intimacy to one another. Family's emotional intimacy is in a way with guidance and values of Sundanese culture. In Sundanese family, there are values which are related to the relationship in a family, specially for the husband and wife. The Sundanese proverb "ari nu laki rabi kudu runtut raut, ka cai jadi saleuwi, ka darat jadi salebak, sapapait, samamanis, sakanyeri sakapeuerih" (Ardiwinata, 2017) means that a husband and a wife must have the same words, suffer from the bad together, enjoy the sweetnees together, suffer from sickness and sadness together. It shows that there are the togetherness and attachment between the husband and wife because they togetherly run the family. Moreover, the husband and wife always love each other, live harmonically, and are respect each other.

Based on the explanation above, the researcher found that:

1) Five themes that become the indicators of psychological strength of Sundanese family;

2) There is an attachment between family of origin and nuclear family that cannot be separated in Sundanese family;

3) Positive characters of family members become factors that influence the psychological strength of family;

4) The closer the family is to Sundanese values and religion, the greater the chance of achieving a strong Sundanese family;

5) The number of children and the presence of children become a factor which can influence the psychological strength of Sundanese family.

\section{E. Conclusion}

This research found five themes that show psychological strength indicators of Sundanese family, as follows 1.) accommodative conflict 
strategy or silih narima 2.) positive communication 3.) family's emotional intimacy 4.) having knowledge (philosophy of life) or neang elmu and 5.) support from family of origin.

To build a strong Sundanese family is inseparable from the understanding of Sundanese cultural values in the family. With the development of the times and issue of globalization era in the city of Bandung, it seems there is a cultural shift in the use of Sundanese language and understanding of Sundanese culture in family.

Based on this research, it can be suggested for further research to explore two family strength indicators are different from previous researches and build the concept of family strength di Sundanese family. Moreover, this research can guide professional families in developing culturally sensitive programs that will effectively enhance strengths in the Sundanese family in Bandung City.

\section{Bibliography}

Afiatin, T. (2018). Psikologi Perkawinan dan Keluarga: penguatan keluarga di era digital berbasis kearifan lokal. Yogyakarta : PT. Kanisius.

Miranti, I., Nurjanah, N., \& Dwiastuty, N. (2018). Learning Local Wisdom for Character Education: an Insight from Choblong Sundanese Village in Indonesia. Jurnal Ilmiah Peuradeun, 6(3), 409-426. doi:10.26811/peuradeun.v6i3.261

Sutrisno, H., Hardiman, G., Pandelaki, E., \& Susi, T. (2019). Living in Harmony: Acculturation of Balinese and Dayak Ngaju Cultures in Basarang Jaya Village, Central Kalimantan. Jurnal Ilmiah Peuradeun, 7(3), 401-412. doi:10.26811/peuradeun.v7i3.279

Ardiwinata, D. (2017). Baruang Kanu Ngarora (Edisi Kiblat Buku Utama. Cetakan Ke-2) . Bandung: Kiblat Buku Utama.

Braun, V., \& Clarke, V. (2006). Using thematic analysis in psychology. Qualitative Research in Psychology, 3(2), p.77-101. Retrieved from http://eprints.uwe.ac.uk/11735/2/thematic_analysis_revised_-_final.pdf.

Brotanek, J. M., Rocha, L. O., \& Flores, G. (2008). Supporting immigrant family strengths: Promoting optimal health, health care, and child development. Zero to Three, 29, 18-25. 
Creswell, J. (2014). Penelitian kualitatif $\mathcal{E}$ desain riset: Memilih di antara lima pendekatan.(A. Lazuardi, Trans.). Yogyakarta: Pustaka Pelajar.

DeFrain, J., \& Asay, S. M. (2007). Strong families around the world: An introduction to the family strengths perspective. Marriage $\mathcal{E}$ Family Review, 41(1-2), 1-10. http:/ / dx.doi.org/10.1300/J002v41n01_01.

DeFrain, J., \& Stinnett, N. (2002). Family strengths. International encyclopedia of marriage and family, 2, 637-652.

DeFrain, J. (2018). The State Of The American Family: The Paradox of How Families And Family Values Are Changing While Staying The Same, RUDN Journal of Sociology. Vol. 18 (1), 73-87.

DeFrain, J., \& Asay, S. M. (2007a). Family strengths and challenges in the USA. Marriage E Family Review, 41(3-4), 281-307.

DeGenova, M. K \& Rice, F.P. (2005). Intimate Relationship, marriages, and families $6 \mathrm{ed}$. New York: McGraw-Hill Companies.

Ekadjati, E.S. (1984). Masyarakat Sunda dan Kebudayaannya. Jakarta : PT. Girimukti Pasaka.

Iqbal, M. (2018). Psikologi Pernikahan : Menyelami Rahasia Pernikahan . Jakarta: Gema Insani.

Iskandar, B. (2012). Citra Perempuan Sunda Di Dalam Karya Sastra Dan Film. Jurnal Sosioteknologi, 26.

Jamil, R. A. (2019). Ritual keagamaan dalam relasi keluarga. In Subandi, Psikologi dan Budaya (Kajian Berbagai Bidang) (pp.82-102). Yogyakarta: Pustaka Pelajar.

Kim, H., Prouty, A. M., Smith, D. B., Ko, M. J., Wetchler, J. L., \& Oh, J. E. (2014). Differentiation of self and its relationship with family functioning in South Koreans. The American Journal of Family Therapy, 42(3), 257-265.

Kusnandar, V.B. (2019). Jawa Barat Provinsi Dengan Penduduk Terbanyak. Retrieved from https://databoks.katadata.co.id/datapublish/2019/09/16/jawabarat-provinsi-dengan-penduduk-terbanyak.

Krysan, M., Moore, K. A., \& Zill, N. (1990). Identifying successful families: An overview of constructs and selected measures. Report preparing by Departemen of Health and Human Services. Retrieved from https://aspe.hhs.gov/system/files/pdf/74316/idsucfam.pdf. 
Lestari, S. (2012). Psikologi keluarga: penanaman nilai dan penanganan konflik dalam keluarga. Jakarta : Kencana Prenada Media Grup.

Lubis, N.H. (2000). Tradisi dan Transformasi Sejarah Sunda I. Bandung : Humaniora Utama Press.

Marlina, H. I. (2006). Kedudukan Wanita Menak dalam Struktur Masyarakat Sunda (Studi Kasus di Kota Bandung). Sosiohumaniora, 8(2), 184.

Medora, N. P., Larson, J. H., \& Dave, P. B. (2000). East-Indian college student's perceptions of family strengths. Journal of Comparative Family Studies, 407-425.

Moore, K. A., Chalk, R., Scarpa, J., \& Vandivere, S. (2002b). Preliminary research on family strengths. Washington DC: Child Trends.

Olson, D. H., Sprenkle, D., \& Russell, C. (1979). Circumplex model of marital and family systems I: Cohesion and adaptability dimensions, family types and clinical applications. Family Process, 18, 3-28. doi:10.1111/j.1545-5300.1979 .00003.x.

Olson, D. H. (2000). Circumplex model of marital and family sytems. Journal of family therapy, 22(2), 144-167.

Otto, H. A. (1962). What is a strong family? Marriage and Family Living, 24, 77-80. doi:10.2307/ 348232.

Otto, H. (1963). Criteria for Assessing Family Strength. Family Process, 2 (2), 329-338. doi: 10.1111/j.1545-5300.1963.00329.x.

Puspitawati, H. (2012). Gender dan Keluarga : Konsep dan Realita di Indonesia. Bogor : PT. IPB Press.

Riyani, I., \& Parker, L. (2018). Women exercising sexual agency in Indonesia. In Women's Studies International Forum (Vol. 69, pp. 9299. doi : https://doi.org/10.1016/j.wsif.2018.05.002.

Roger. (1999). The Sundanese People, West Java, Indonesia. Retrieved from http://www.sunda.org/sundanese/sundanese.htm\#centuryreform.

Rosidi, A. (1984). Ciri-Ciri Manusia dan Kebudayaan Sunda. In Ekadjati, Masyarakat Sunda dan Kebudayaannya (pp.127-161). Jakarta : PT. Girimukti Pasaka.

Sari, Y., Kurnia, S.S.,\& Sundaya,Y.(2016). The Risk of Divorce : style of communication, stages of family development and type of 
socioeconomic status. International Journal of Culture and History, 2 (1), 5-8. doi: 10.18178/ijch.2016.2.1.028 H.

Setiawan, H. (2011, February). Anak Tanah Sunda. Paper presented at the Sundanese Culture and Behavior Seminar, Bandung, Indonesia.

Stinnett, N., Chesser, B., \& DeFrain, J. D. (1979). Building family strengths. University of Nebraska Press.

Setiono, K. (2011). Psikologi Keluarga. Bandung : PT. Alumni.

Siddik, B. (2015). Representasi Kecantikan Perempuan Sebagai Media Pemikat Laki-Laki Dalam Mitos Marongge. Jurnal Riksa Bahasa, 1(2).

Sittner, B.J., Hudson, D.B.,DeFrain, J. (2007) Using Concept of Family Strengths to Enhance Nursing Care. Journal Maternal Child Nursing, $2007 \quad$ Nov-Dec,32 doi:10.1097/01.NMC.0000298130.16914.47.

(6), 353-357.

Suhamihardja, A. (1984). Organisasi Dan Struktur Sosial Masyarakat Sunda. In Ekadjati, Masyarakat Sunda dan Kebudayaannya (pp. 205222). Jakarta: PT. Girimukti Pasaka.

Sunarti, E. (2015). Ketahanan Keluarga Indonesia: dari Kebijakan dan Penelitian Menuju Tindakan. Orasi Ilmiah Guru Besar IPB. Auditorium Rektorat, Gedung Andi Hakim Nasoetion Institut Pertanian Bogor, 6 Juni 2015. Bogor : PT Penerbit IPB Press.

Suryalaga, H. (2009). Kasundaan Rawayan Jati. Bandung: Yayasan Nur Hidayat.

Suryadinata, L., Arifin, E. N., \& Ananta, A. (2003). Indonesia's population: Ethnicity and religion in a changing political landscape (No. 1). Institute of Southeast Asian Studies.

Suryani, E., Diria, M., Adipurwawidjana, A., Erlyane,A. Hudayat, A.Y. (2002). Peran Wanita Sunda dalam Karya Sastra Sunda: Suatu Kajian Gender. Jakarta : Pusat Bahasa Departemen Pendidikan Nasional.

Trivette, C. M., Dunst, C. J., Deal, A. G., Hamer, A. W., \& Propst, S. (1990). Assessing family strengths and family functioning style. Topics in Early Childhood Special Education, 10(1), 16-35.

Utaridah, N. ( 2015). Representasi citra laki-Laki budaya sunda (studi analisis semiotik charles sanders peirce dalam sinetron preman pensiun). Jurnal Sosiologi,17(2),135-147. 
Warnaen,S., Djiwapraja, D., Wibisana, W., Adimijardja, K., Sukmana, N., \& Rostoyati, O. (1986). Pandangan Hidup Orang Sunda Seperti Tercermin Dalam Tradisi Lisan dan Sastra Sunda. Bandung. Penelitian I. Penerbit : Bagian Proyek Penelitian dan Pengkajian Kebudayaan Sunda (Sundanologi) Direktorat jendral Kebudayaan. Departemen Pendidikan dan Kebudayaan Bandung.

Warnaen, S. dkk.(1987). Pandangan Hidup Orang Sunda. Bandung: Bagian Proyek Penelitian dan Pengkajian Kebudayaan Sunda (Sundanologi) Depdikbud.

Wong, A., Y. Wong,Y.,J., \& Obeng, C.,S. (2012). An Untold Story: A Qualitative Study of Asian American Family Strengths. Asian American Journal of Psychology., 3 (4), 286-298. doi: $10.1037 / \mathrm{a} 0025553$.

Yuliawati, S., Hidayat, R., Rahyono, F., Kwary, D. (2017). Pilihan Kata Dan Konstruksi Perempuan Sunda Dalam Majalah Manglè: Kajian Linguistik Korpus Diakronik. Jurnal Kajian Budaya, 7(2), 138-15 3. doi: 10.17510/paradigma. v7i2.172. 